\title{
Distribution of the rare earth elements in the sediments of the Bouregreg river (Morocco) using the instrumental neutron activation analysis (INAA).
}

\section{${ }^{1}$ HAMID BOUNOUIRA; *1 ABDELMAJID CHOUKRI; ${ }^{2}$ RAJAA CHERKAOUI ELMOURSLI; ${ }^{1}$ OUM KELTOUM HAKAM; ${ }^{3}$ SAID CHAKIRI}

\author{
1 *Equipe de Physique et Techniques Nucléaires, Laboratoire de Physique de la Matière et Rayonnement, Université Ibn Tofail, Faculté des \\ Sciences, B.P.133,14000,Kénitra, Morocco.choukrimajid@yahoo.com \\ ${ }^{2}$ Laboratoire de Physique Nucléaire, Université Mohammed V-Agdal, Faculté des Sciences, 4 Avenue Ibn Battouta B.P. 1014 RP, Rabat \\ Morocco \\ ${ }^{3}$ Equipe de Géomatériaux et Environnement, Laboratoire des Géosciences Appliquée, Université Ibn Tofail, Faculté des Sciences, B.P. 133, \\ 14 000, Kénitra, Morocco.
}

\begin{abstract}
Rare earth elements (REE), define a group of fifteen chemical elements from lanthanum to lutetium (atomic numbers 57-71) characterized by similar chemical properties. To study their distribution in sediment samples of the Bouregreg river and its tributaries, 10 sampling sites have been chosen. The collected sediment samples were analysed by instrumental neutron activation analysis (INAA) using the Orphée and Osiris reactors of CEA Saclay (France). The chondritic normalisation curves show enrichment in light rare earth elements (LREE), a negative Eu anomaly in several samples, and a progressive depletion of heavy rare earth elements (HREE). Two hypotheses are discussed: the nature of parent rocks of these sediments and the phisico-chemical conditions of sedimentation especially complexation and oxydo-reduction phenomenons.@JASEM
\end{abstract}

The rare earth elements (REE, from La through to $\mathrm{Lu}$ ) are a coherent geochemical group characterized by a single oxidation state: REE (III) except for cerium and europium. During the last few decades, REE have become important geochemical tracers in order to understand and describe the chemical evolution of the earth's continental crust (Goldstein and Jacobsen., 1988; McLennan., 1989; Gaillardet., 1995; Dupre et al., 1996). Moreover, REE have been used, as analogues for actinide elements, in studies related to radioactive waste disposal in order to demonstrate their general immobility in weathering environments (Wood., 1990). Despite this, many studies have indicated that REE may be significantly mobilized during weathering and that REE may behave nonconservatively (Braun et al., 1990; Sholkovitz et al., 1994). However, little is known about REE distribution and fractionation during weathering and river transport.

The purpose of this study is to study the distribution of rare earth elements in sediment samples collected in the Bouregreg in Morocco. We present here the first results of this new action. In this perspective, a methodology, implementing the analysis by instrumental neutron activation analysis (INAA) was elaborated. It combines a sampling device covering the set of the basin, taking into account the lithological variety of the Bouregreg river basin.

\section{MATERIALS AND METHODS}

Sampling: Sediment samples were collected from ten locations along the $200 \mathrm{~km}$ course of the Bouregreg river (Morocco) from its source to the vicinity of its estuary, near Rabat (Fig 1). The Bouregreg river is one of the main streams of Morocco. Its source is located in the Moroccan Central Massif and flows towards the Atlantic coast through the coastal Meseta. The Bouregreg river basin is located in the Moroccan Central Massif which consists mainly of Palaeozoic formations (essentially combro-ordovician detrital formations). Furthermore, the Central Moroccan Massif is characterized by the presence of many plutonic Hercynian granites covering a rather wide geographical area. Those localised in the Bouregreg river basin correspond to the Ment, Oulmès and Moulay Bou Azza granites. Figure 1 displays the Bouregreg river basin in the Moroccan Central Massif and sampling points. Sampling sites were selected in order to represent most of the main lithological heterogeneities and the distribution of the anthropogenic activities along the Bouregreg basin.

Sample preparation: Sediment samples were collected at distances of $20 \mathrm{~cm}$ from the banks of the river, using polyethylene bags. Samples were dried during 24 hours in an oven at $105^{\circ} \mathrm{C}$, then crushed in an agate mortar, homogeneized and stored in polyethylene bags until analyses. Care was taken to avoid contamination during sampling, drying, grinding, sieving and storage. The particles less than $100 \mu \mathrm{m}$ were used for analysis.

INAA measurements: All samples irradiations were carried out at Laboratoire Pierre Sue (LPS), directly connected to the two nuclear reactors (Osiris and 
Orphée) of the CEA Saclay Center (France). For short irradiations, in the ORPHEE channels, about $100 \mathrm{mg}$ of sample were sealed into a pure polyethylene container and placed with 3 to $6 \mathrm{mg}$ of IRMM-530 gold wire( $\mathrm{Al} / \mathrm{Au}$ alloy containing certified $0,100 \%$
$\mathrm{Au})$ as a neutron flux monitor in a polyethylene shuttle and irradiated from $30 \mathrm{~s}$ to $2 \mathrm{~min}$. After irradiation, four countings were carried out for each sample for 2, 5, 15 and $60 \mathrm{~min}$, respectively.

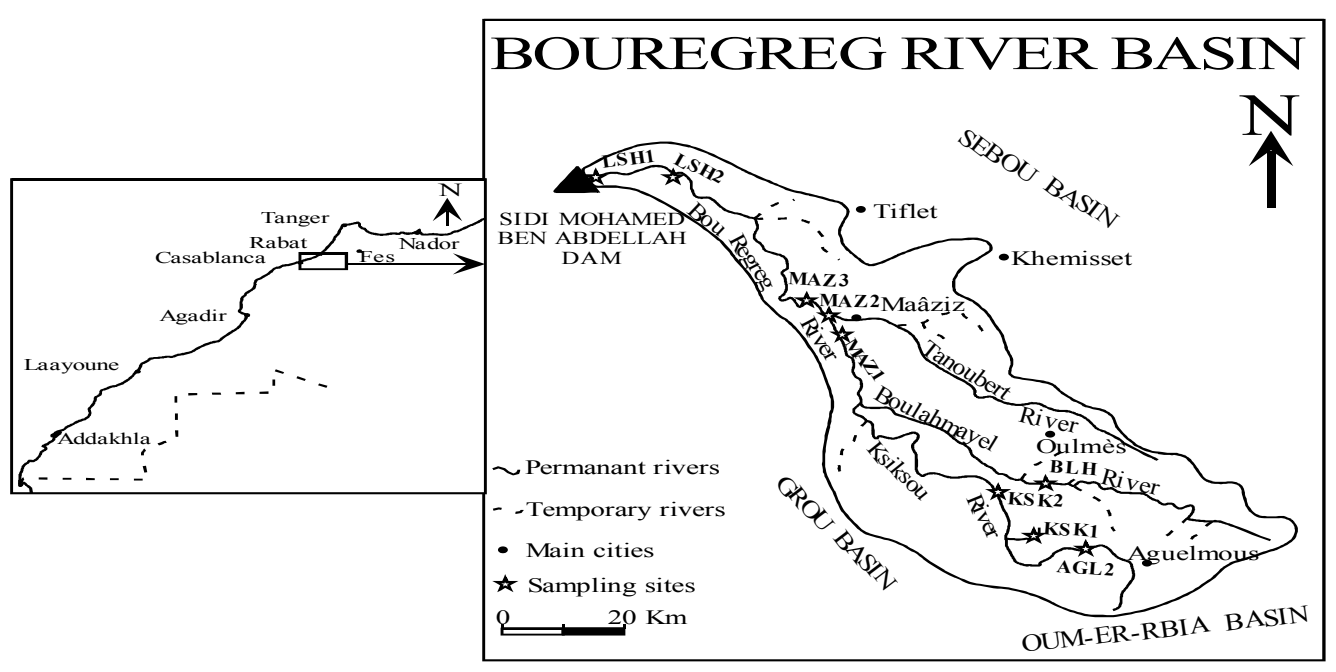

Fig1: Location of the Bouregreg River basin in the Moroccan Central Massif and sampling points.

For long irradiations, in the ORPHEE channels, each $100 \mathrm{mg}$ samples were wrapped in high purity aluminum foil. They were placed in an aluminum shuttle which contained up to 10 samples. A Fe flux monitor and one $100 \mathrm{mg}$ sample of the Certified Reference Material (Soil7), provided by the International Atomic Energy Agency were prepared similarly. The irradiation time was 7 hours. After irradiation, samples were measured three times on an HPGe detector after 7, 15 and 30 days decay time. Irradiations were also performed under a cadmium wall (Epithermal neutron activation analysis, or ENAA) to select epithermal and rapid neutrons in the OSIRIS reactor. Such thermal and epithermal irradiations were developed at LPS by Joron et al., 1997 and Raimbault et al., 1997. They were applied for the determination of, $\mathrm{La}, \mathrm{Ce}, \mathrm{Nd}, \mathrm{Sm}, \mathrm{Eu}, \mathrm{Tb}, \mathrm{Yb}$ and $\mathrm{Lu}$, by using both reactors. The concentrations were calculated using the $\mathrm{K}_{0}$ LABSUE software (Piccot., 1997). The compilation data (mean and standard deviation) were calculated from the average values taking into account the number of results. In general, results are given with 3 times the standard deviation $(3 \sigma)$, corresponding to a confidence interval of $99 \%$.

\section{RESULTS AND DISCUSSION}

In this work, the analysis of the correlation matrix realized on the rare earth elements puts in evidence of very strong bonds between various rare earths. Correlation coefficients indicate that bonds between these elements are stronger, on one hand, between the lightest rare earths ( $\mathrm{La}, \mathrm{Ce}, \mathrm{Nd}$ and $\mathrm{Sm}$ ) and on the other hand, between the heaviest rare earth $(\mathrm{Tb}, \mathrm{Dy}$, $\mathrm{Yb}$ and $\mathrm{Lu}$ ). The correlation coefficients are all superior to 0,945 for the first group, for the second group the correlation coefficient is superior to 0,635 . We can notice the good correlation of $\mathrm{Tb}$ with the light rare earths (coefficient of correlation superior to 0,651) and the correlation among $\mathrm{Sm}$ and $\mathrm{Yb}$.

Table 1: Correlation matrix of the rare earth in sediments of Bouregreg river.

\begin{tabular}{cccccccccc}
\hline & $\mathrm{La}$ & $\mathrm{Ce}$ & $\mathrm{Nd}$ & $\mathrm{Sm}$ & $\mathrm{Eu}$ & $\mathrm{Tb}$ & $\mathrm{Dy}$ & $\mathrm{Yb}$ & $\mathrm{Lu}$ \\
\hline $\mathrm{La}$ & 1,00 & & & & & & & & \\
$\mathrm{Ce}$ & 0,98 & 1,00 & & & & & & & \\
$\mathrm{Nd}$ & 0,96 & 0,98 & 1,00 & & & & & & \\
$\mathrm{Sm}$ & 0,95 & 0,95 & 0,99 & 1,00 & & & & &
\end{tabular}




\begin{tabular}{llllllllll}
$\mathrm{Eu}$ & 0,44 & 0,52 & 0,38 & 0,26 & 1,00 & & & & \\
$\mathrm{~Tb}$ & 0,76 & 0,69 & 0,65 & 0,69 & 0,29 & 1,00 & & & \\
$\mathrm{Dy}$ & 0,35 & 0,27 & 0,35 & 0,48 & $-0,30$ & 0,68 & 1,00 & & \\
$\mathrm{Yb}$ & 0,49 & 0,44 & 0,54 & 0,63 & $-0,40$ & 0,50 & 0,72 & 1,00 & \\
$\mathrm{Lu}$ & 0,48 & 0,38 & 0,47 & 0,58 & $-0,43$ & 0,64 & 0,84 & 0,92 & 1,00 \\
\hline
\end{tabular}

In order to illustrate the spatial distribution of rare earths, their respective concentrations were expressed in ppm. However, as their abundance varies according to the parity of their atomic number (making thus difficult the study and the comparison of the curves), the distribution diagrams were represented by standardizing the abundance of rare earths compared to chondrites $(\mathrm{C} 1)$ data estimated by Taylor and McLennan., 1985, and the diagrams of their distribution (Fig 2) were established according to their atomic number.

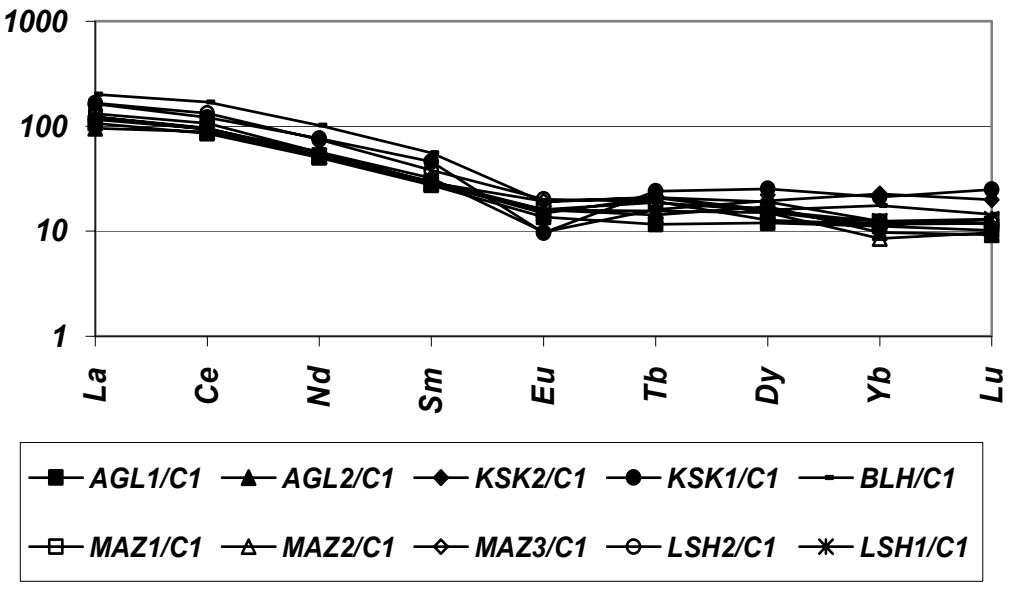

Fig 2: Composition of the Bouregreg river sediments normalized to chondrites using values of Taylor and McLennan (1985).

The obtained profiles (Fig 2) show an enrichment in the LREE (La, Ce, Nd and $\mathrm{Sm}$ ) and a depletion in HREE (Tb, Dy, Yb and Lu), with a light negative anomaly in Eu in the totality of the catchment area of Bouregreg. One can thus consider that the standardized spectra of rare earth of the samples of sediments of the Bouregreg river are equivalent to that of the upper continental crust as a whole. This latter containing rocks with rare earth concentrations much weaker (siliceous sandstone, limestones, evaporites). The hypothesis of an anthropogenic contribution related to the use of phosphate-enriched fertilizers (Martin and McCulloch., 1999) cannot be certified. Indeed, on the one hand, the all the sites concerned with enrichment LREE are not located in agricultural zones; whereas, other sites entirely located in agricultural zone do not present this anomaly. The lithological diversity met in the Bouregreg river basin slopes seems to better account for the observed anomaly, as well as the physicochemical conditions of the medium of sedimentation more particularly the phenomena of complexation and oxydoreduction.

Conclusions: In this work, we used the instrumental neutron activation analysis to study the distribution of rare earths elements in the sediments samples of the Bouregreg river basin. The nuclear method used offers a great sensitivity and a good selectivity for the analysis of the sediments. This study shows that the rare earths set up a complex group. A behaviour differentiated from light rare earths very strongly dependent between them ( $\mathrm{La}, \mathrm{Ce}, \mathrm{Nd}$ and $\mathrm{Sm}$,) and from heavy rare earths ( $\mathrm{Tb}, \mathrm{Dy}, \mathrm{Yb}$ and $\mathrm{Lu})$ is highlighted on certain sites of the catchment area of Bouregreg. One cannot however confirm that enrichments out of light rare earths observed are related to an agricultural pollution. On the other hand lithology could exploit an unquestionable part this enrichment.

Acknowledgements: This work was carried out in a PhD study (BOUNOUIRA, 2003-2006) supported by the Action Intégrée franco-marocaine (MA/02/43) and the PROTARS II projects (P21/60 and PII/03).

\section{REFERENCES}

Braun J. J., Pagel M., Muller J. P., Bilong P., Michard A., and Guillet B., (1990) Cerium anomalies in lateritic profiles. Geochim. Cosmochim. Acta 54, $781-795$ 
Dupre B., Gaillardet J., Rousseau D., and Allegre C., (1996) Major and trace elements of river-borne material: the Congo Basin. Geochim. Cosmochim. Acta 60, 1301-1 321

Gaillardet J., (1995) Géochimie comparée de deux grands systèmes fluviaux tropicaux : le Congo et I'Amazone. Géochimie isotopique du bore dans les coraux. Thesis, Univ. Pierre-et-Marie-Curie, Paris-6, France, 427 pp.

Goldstein S J., and Jacobsen S. B., (1988) Rare earth elements in river waters. Earth Planet. Sci. Lett $89,35-47$.

Govindaraju K., (1995) Working values with confidence limits for twenty-six CRPG, ANRT and IWG-GIT geostandards. Geostandards Newsletter, XIX, 1-32.

JORON J. L., TREUIL M., and RAIMBAUT L., (1997) Activation analysis as a geochemical tool: Statement of its capabilities for geochemical trace element studies. Journal of Radioanalytical and Nuclear Chemistry 216 (2), 229 - 235

Martin C. E., and McCulloch, M., (1999) Nd-Sr isotopic and trace element geochemistry of river sediments and soils in a fertilized catchment, New South Wales, Australia. Geochimica et Cosmochimica Acta, 63(2), 287-305.
McLennan S. M., (1989) Rare earth elements in sedimentary rocks: influence of the provenance and sedimentary process, in: Geochemistry and Mineralogy of Rare Earth Elements 21, 169-200

PICCOT D., DESCHAMPS C., DELAMAS R., and REVEL R., (1997) Ko-LABSUE: a quasi nondependent data format package forkoquantification. Journal of Radioanalytical and Nuclear Chemistry 215(2), 263-269.

RAIMBAULT L., PEYCELON H. and JORON J. L., 1997., Single-crystal trace element analysis in rock-forming minerals by instrumental neutron activation analysis. Journal of Radioanalytical and Nuclear Chemistry 216 (2), $221-228$

Sholkovitz E. R., Landing W.M., and Lewis B. L., (1994) Ocean particle chemistry: the fractionation of rare earth elements between suspended particles and seawater. Geochim. Cosmochim. Acta 58, 1567-1579

Taylor S. R., and McLennan S. M., (1985) The Continental Crust: Its Composition and Evolution: Oxford (Blackwell Scientific).

Wood S. A., (1990). The aqueous geochemistry of rare-earth elements and yttrium. Chem. Geol. 82, 159-1 86 